КРИМІНАЛЬНЕ ПРАВО ТА КРИМІНОЛОГІЯ;

КРИМІНАЛЬНО-ВИКОНАВЧЕ ПРАВО

УДК 343.301

DOI https://doi.org/10.32844/2618-1258.2019.6.46

КАРМАН В.В.

\title{
СУБ'ЄКТИВНА СТОРОНА НАРУГИ НАД ДЕРЖАВНИМИ СИМВОЛАМИ УКРАЇНИ
}

У статті наголошено, що встановлення суб'єктивної сторони складу злочину має вкрай важливе значення, крім того, серед усіх обов'язкових ознак найбільш складно встановити саме іiі. Для того аби розкрити суб'єктивну сторону наруги над державними символами України, цілком логічно визначити зміст цієї ознаки. У науці кримінального права, як правило, під суб' єктивною стороною злочину розглядають внутрішню сторону злочину, тобто психічну діяльність особи, що відображає ставлення іiі свідомості та волі до вчиненого нею суспільно небезпечного діяння і до його наслідків. Суб'єктивна сторона злочину складається з обов'язкових та факультативних ознак. До обов'язкових ознак належить вина, яка згідно зі ст. 23 КК може бути виражена у формі умислу або необережності, а до факультативних мотив і мета. Визначено, що для злочинів із формальним складом характерна лише умисна форма вини, вид умислу - прямий. Дане правило стосується і злочину у вигляді публічної наруги над державними символами України. Дійсно, складно не погодитись із тим, що, вчиняючи ці дії, суб'єкт злочину розуміє суспільно небезпечний характер своїх дій і бажає їх вчинити. 3'ясовано, що в більшості випадків у судових вироках за ч. 1 ст. 338 КК України суди акцентують увагу на тому, що суб' єкту злочину притаманна умисна форма вини (62,5\% випадків). Крім того, в судовій практиці відсутні випадки, в яких би було встановлено, що особа, яка вчинила діяння у вигляді наруги над державними символами України, діяла необережно. Встановлено, що обов'язковою ознакою суб'єктивної сторони складу суспільно небезпечного діяння у вигляді наруги над державними символами України $є$ вина, що виражається у формі умислу, вид умислу - прямий. Факультативними ознаками суб' єктивної сторони складу злочину, передбаченого ч. 1 ст. 338 КК України, можуть виступати мотив (на практиці виявлено дві групи мотивів: явної неповаги до України та явної неповаги до суспільства) та мета (на практиці зустрічається два випадки встановлення мети: підривання авторитету держави та приниження тих цінностей, до яких інші члени суспільства ставляться з повагою), втім, у більшості випадків, на жаль, суди не приділяють уваги встановленню цих ознак.

Ключові слова: право, закон, злочин, авторитет держави, державні символи, наруга, підстави криміналізаиії.

The article emphasizes that establishing the subjective side of the crime is of the utmost importance, and it is also the most difficult of all the mandatory features to establish it. In order to reveal the subjective side of the insult against the national symbols of Ukraine, it is logical to determine the content of this feature. In the science of criminal law, as a rule, the subjective side of crime is considered the inner side of the crime, that is, the mental activity of a person, which reflects the attitude of his consciousness and will to the act of socially dangerous act and its consequences. The subjective side of a crime

(C) КАРМАН В.В. - здобувач (Науково-дослідний інститут публічного права) 
consists of mandatory and optional features. Required signs include wine, which according to Art. 23 of the Criminal Code can be expressed in the form of intent or negligence, and to the optional - motive and purpose. It is determined that crimes with a formal composition are characterized only by a deliberate form of guilt, the type of intent is direct. This rule also applies to crime in the form of public abuse of state symbols of Ukraine. Indeed, it is difficult to disagree that by committing these acts, the subject of the crime understands the socially dangerous nature of his actions and wishes to commit them. It is found that in most cases in court sentences under Part 1 of Art. 338 of the Criminal Code of Ukraine the courts emphasize that the subject of the crime has a deliberate form of guilt (62.5\% of cases). In addition, there is no case law in which it would be established that a person who committed acts of abuse of state symbols of Ukraine acted negligently. It is established that the obligatory sign of the subjective side of the composition of socially dangerous act in the form of insulting the state symbols of Ukraine is the wine, which is expressed in the form of intent, the kind of intent - direct. Optional features of the subjective side of the crime under Part 1 of Art. 338 of the Criminal Code of Ukraine may be a motive (in practice, two groups of motives are revealed: a clear disrespect for Ukraine and a clear disrespect for society) and a goal (in practice, there are two instances of goal setting: undermining the authority of the state and degrading those values to which other members of society relate to respect), however, in most cases, unfortunately, the courts do not pay attention to establishing these features.

Key words: law, law, crime, authority of the state, state symbols, abuse, grounds for criminalization.

Постановка проблеми. Встановлення суб'єктивної сторони складу злочину відіграє вкрай важливе значення, крім того, серед усіх обов'язкових ознак найбільш складно встановити саме їі. Для того аби розкрити суб'єктивну сторону наруги над державними символами України, цілком логічно визначити зміст цієї ознаки.

У науці кримінального права, як правило, під суб'єктивною стороною злочину розглядають внутрішню сторону злочину, тобто психічну діяльність особи, що відображає ставлення їі свідомості та волі до вчиненого нею суспільно небезпечного діяння і до його наслідків [1, с. 113].

Таким чином, суб'єктивна сторона - це сукупність психічних та вольових процесів, що відбуваються у свідомості суб'єкта злочину.

Не будемо виходити від традиційної думки та скористаємось саме цим положенням під час дослідження суб'єктивної сторони складу злочину, передбаченого ч. 1 ст. 338 КК України.

Як зауважують О.О. Дудоров та М.I. Хавронюк, суб'єктивна сторона злочину складається з обов'язкових та факультативних ознак. До обов'язкових ознак належить вина, яка згідно зі ст. 23 КК може бути виражена у формі умислу або необережності, а до факультативних - мотив i мета. Дві останні ознаки допомагають відповісти на питання, чому і для чого вчинено діяння. Мотив і мета набувають значення обов'язкових ознак і впливають на кваліфікацію лише в тому разі, коли вони зазначені в диспозиції кримінально-правової норми як ознаки основного або кваліфікованого складу кримінального правопорушення. Наприклад, одним із кваліфікованих різновидів умисного вбивства $є$ вбивство, вчинене з метою приховати інший злочин або полегшити його вчинення (п. 9 ч. 2 ст. 115 КК). Мета збуту є ознакою складу злочину, передбаченого ст. 307 КК («Незаконне виробництво, виготовлення, придбання, зберігання, перевезення, пересилання чи збут наркотичних засобів, психотропних речовин або їх аналогів»), а мета заподіяння шкоди інтересам держави - ознакою складу злочину, передбаченого ст. 332-1 КК («Порушення порядку в’їзду на тимчасово окуповану територію України та виїзду з неї») [2, с. 184].

Із наведеного випливає, що суб'єктивна сторона складу злочину складається із трьох ознак: вини, мотиву та мети. При цьому лише вина є обов'язковою ознакою суб'єктивної сторони будь-якого складу злочину, тоді як мотив та мета мають таку ж роль лише в окремих, визначених КК України випадках.

Виклад основного тексту. Позиція, відповідно до якої суб'єктивна сторона злочину складається з чотирьох елементів: вина, мотив, мета та емоційний стан - має право на життя. У такому разі лише вина $є$ обов'язковою ознакою будь-якого злочину, тоді як решта - тільки в окремих складах злочинів.

Диспозиція ч. 1 ст. 338 КК України передбачає єдину обов’язкову ознаку суб'єктивної сторони наруги над державними символами України - вину. Вина займає одне з найважливіших 
місць у складі будь-якого злочину. Так, згідно зі ст. 62 Конституції України особа вважається невинуватою у вчиненні злочину і не може бути піддана кримінальному покаранню, доки ії вину не буде доведено в законному порядку і встановлено обвинувальним вироком суду [3].

Саме згадка категорії «вина» в Конституції України в черговий раз підтверджує важливість цієї суб'єктивної ознаки, доведення якої є однією з найважливіших підстав притягнення особи до кримінальної відповідальності.

Як зазначає Р.В. Вереша, ознаки прямого умислу, що вказані в ч. 2 ст. 24 КК України, характерні для так званих матеріальних злочинів (кримінальних правопорушень 3 матеріальним складом), необхідною складовою частиною яких $є$ настання певних суспільно небезпечних наслідків, передбачених законом, і наявність причинного зв'язку між діянням особи і наслідками, що настали. Тому у випадку вчинення цих злочинів винуватий передбачає не тільки суспільно небезпечні наслідки свого діяння, але й у загальних рисах - розвиток причинного зв'язку між діянням, що вчиняється, і злочинним наслідком, що настане [4, с. 76].

Нагадаємо, раніше нами було доведено, що діяння у вигляді публічної наруги над державними символами України відноситься до злочинів із формальним, а не матеріальним складом.

Викладене зауваження має вагоме значення, адже в цих складах злочинів, на думку Р.В. Вереши, вина проявляється дещо інакше. Відтак вчений наполягає на тому, що в так званих формальних злочинах (кримінальних правопорушеннях з формальним складом), склад яких не передбачає як необхідну складову частину настання певних суспільно небезпечних наслідків, змістом прямого умислу є усвідомлення винуватою особою суспільно небезпечного характеру своєї дії або бездіяльності і бажання ії вчинення (статті 113, 304, 344 КК України та ін.). Характерною ознакою прямого умислу є також бажання настання злочинного наслідку, що був задуманий, щодо матеріальних злочинів, і бажання вчинення злочинного діяння - щодо формальних злочинів. У такого роду бажанні знаходить свій вираз вольова ознака умислу як його найважливіша і відмінна риса. Наявністю бажання настання злочинного наслідку під час вчинення злочину 3 матеріальним складом прямий умисел відрізняється від інших форм і видів вини. Бажання, як вольове начало, перебуває в нерозривній єдності із свідомістю особи, яка діяла із прямим умислом, і ії̈ здатністю передбачити наслідки свого діяння [4, с. 77].

Із вказаних роздумів опосередковано випливає, що для злочинів із формальним складом характерна лише умисна форма вини, вид умислу -прямий. Дане правило стосується і злочину у вигляді публічної наруги над державними символами України. Дійсно, складно не погодитись із тим, що, вчиняючи ці дії, суб'єкт злочину розуміє суспільно небезпечний характер своїх дій i бажає їх вчинити.

На користь підходу, відповідно до якого злочинам із формальним складом притаманна виключно умисна форма вини у вигляді прямого умислу, висловлюються і В. Куц та О. Бондаренко, які наголошують на тому, що необхідною та достатньою умовою наявності вини у злочинах із формальним складом можна вважати усвідомлення особою суспільно небезпечного характеру свого діяння та бажання його вчинити, але за умови, що усвідомлення суспільної небезпечності діяння розуміється як результат усвідомлення його наслідків, а бажання вчинити злочинне діяння одночасно означає наявність бажання досягти злочинних наслідків. Та обставина, що ці наслідки у формальному складі злочину «опинилися» за межами складу, жодним чином не змінює змісту вини суб'єкта. Модифікується у формальному складі злочину порівняно з матеріальним складом лише форма вина, а не її зміст [5, с. 38].

Погоджуємось із висловленими аргументами, які підтверджують думку про те, що суб'єктивна сторона злочину у вигляді наруги над державними символами України виражається виною у формі умислу, вид умислу - прямий. Для остаточного доведення цієї тези звернемося до судової практики.

Проаналізувавши викладені в Сдиному державному реєстрі судових рішень вироки за ч. 1 ст. 338 КК України (станом на 23.11.2019 року - 32 вироки), ми виявили 20 випадків, коли судом у вироку було наголошено на тому, що суб'єкт злочину діяв умисно.

Наприклад, у вироці Южного міського суду Одеської області від 22.02.2019 року у справі № 519/816/17 судом встановлено, що 20.09.2017 року о 06 год. 07 хв., ОСОБА_1, перебуваючи у стані алкогольного сп'яніння, знаходячись на території ділянки для відпочинку, розташованої за адресою Одеська область, м. Южне, вул. Т.Г. Шевченка, навпроти житлового багатоквартирного будинку № 7, діючи умисно, усвідомлюючи суспільно небезпечний характер свойх дій, розуміючі, що вони порушують порядок використання державних символів України, принижують ї̈ автоpuтет і бажаючи вчинити такі дï̈, публічно наругався над державним символом України - Дер- 
жавним Прапором України, що виразилось у зриванні піднятого Державного Прапору України та його пошкодженні [6].

Отже, в більшості випадків у судових вироках за ч. 1 ст. 338 КК України суди акцентують увагу на тому, що суб'єкту злочину притаманна умисна форма вини (62,5 \% випадків). Крім того, в судовій практиці відсутні випадки, в яких би було встановлено, що особа, яка вчинила діяння у вигляді наруги над державними символами України, діяла необережно.

Ураховуючи ж ситуації, описані в решті вироків, можна дійти висновку, що в них суб'єкт злочину також, однозначно, діяв умисно. У даному контексті цікавою виглядає ситуація, описана у вироці Мукачівського міськрайонного суду Закарпатської області від 20 грудня 2018 року у справі № 303/6698/18. Допитаний у судовому засіданні обвинувачений ОСОБА_1 свою вину у вчиненні інкримінованого йому злочину не визнав. При цьому зазначив, що дійсно перебував 19 вересня 2018 року близько 04 години 00 хвилин у центрі міста Мукачева зі своїми друзями ОСОБА_4 та знайомим на ім'я Роман. Проходячи повз адміністративної будівлі на площі Духновича, 2 у місті Мукачеві побачив, що прапор закріплений жовтою смугою догори. Будучи патріотом своєї країни, учасником бойових дій (перебував у зоні АТО із травня по липень 2015 року) не міг допустити такого порушення, тому вирішив встановити прапор належним чином. Піднявшись по стіні, намагався зняти прапор, але не втримався і впав на землю, його знайомі підішли до нього, допомогли піднятися. Деякий час вони розмовляли неподалік від будівлі. Згодом він знову вирішив перевернути прапор з метою його належного встановлення, але не втримався та впав разом із прапором. Коли піднявся, сильний порив вітру вирвав з його рук прапор, і той впав на землю. Один із товаришів підняв прапор і передав йому. Після чого він хотів поставити прапор на клумбу, але в нього не вийшло, тому забрав прапор із собою. Куди подівся прапор, йому невідомо, оскільки після падіння зі стіни будівлі погано себе почував і нічого не пам'ятає про події, які відбувалися згодом [7].

Зі слів обвинуваченого сумніву піддається не лише форма вини, але і взагалі її наявність. Ситуація знову демонструє всю складність розкриття та доведення суб'єктивної сторони складу злочину. Утім, дану справу вдалося об'єктивно вирішити. Так, під час перегляду в суді відеозапису з камери зовнішнього спостереження встановлено, що саме обвинувачений у присутності сторонніх осіб із фасаду над головним входом до адміністративної будівлі органу місцевого самоврядування Мукачівської міської ради на площі Духновича, 2 у місті Мукачеві зірвав флагшток із прапором. Також із даного відеозапису вбачається, що прапор встановлений належним чином. Обвинувачений, намагаючись зірвати прапор, декілька хвилин розхитував кріплення, на якому було встановлено флагшток із прапором. Зірвавши прапор, обвинувачений кинув його на землю, після чого відразу підняв і забрав із собою [7].

Саме завдяки відеозапису вдалося розкрити неправдивість свідчень суб'єкта злочину та встановити форму його вини - умисел.

Отже, в більшості випадків суди визначають лише форму вини у вироках за ч. 1 ст. 338 КК України - умисна, проте не визначають вид умислу (можливо через те, що він не впливає на кваліфікацію).

Не дивлячись на це, на підставі комплексу аргументів (зміст поняття «наруга»; позиція більшості вчених про те, що злочинам із формальним складом притаманна лише умисна форма вини у вигляді прямого умислу; наявна наукова позиція щодо змісту суб'єктивної сторони у складі злочину у вигляді наруги над державними символами України [8, с. 563; 9, с. 1050; 10, с. 449], судова практика) можна зробити висновок про те, що суб'єктивна сторона злочину, передбаченого ч. 1 ст. 338 КК України, виражена виною у формі умислу, вид умислу - прямий.

Мотиви та мета є факультативними ознаками суб'єктивної сторони складу злочину у вигляді наруги над державними символами України.

Під мотивами прийнято розглядати внутрішні усвідомлені спонукання, якими керується особа під час вчинення злочину [11, с. 48]. Судова практика, на жаль, демонструє, що суди в більшості випадків ігнорують встановлення мотивів та мети наруги над державними символами України. Утім, все ж таки в поодиноких випадках дані факультативні ознаки суб'єктивної сторони складу злочину розкриваються.

У вироку Городоцького районного суду Львівської області від 30 серпня 2018 року у справі № 441/1001/18 ОСОБА_1, 22 травня 2018 р., о 22 год. 20 хв., перебуваючи на площі між майданом Гайдамаків та вул. Леся Мартовича у м. Городок Львівської області, поблизу монументу «Пам'яті жертв сталінських репресій», із мотивів явної неповаги до Украйни підійшов до місця встановлення Державних Прапорів України на вищевказаному монументі і з використанням за- 
пальнички умисно пошкодив два прапори України, що виразилось в умисному підпалі тканини обох прапорів, та, продовжуючи свій злочинний умисел, залишив їх догорати та частково спалив ïx, чим скоїв публічну наругу над Державним Прапором України [12].

У даному випадку судом було встановлено факультативну ознаку суб'єктивної сторони наруги над державними символами України - мотив, що виражається в явній неповазі до нашої держави.

Крім означених мотивів, у судовій практиці зустрічаються також випадки встановлення мотивів явної неповаги до державних символів (вирок Мукачівського міськрайонного суду Закарпатської області від 20 грудня 2018 року по справі № 303/6698/18 [7]), хуліганських мотивів (вирок Коростенського міськрайонного суду Житомирської області від 03 квітня 2019 року по справі № 279/1037/19 [13]) та мотивів явної неповаги до суспільства (вирок Лановецького районного суду Тернопільської області від 15 листопада 2012 року по справі № 1910/896/2012 [14]).

Мотиви явної неповаги до суспільства $є$ майже тотожними мотивам явної неповаги до України, адже, як було встановлено вище, в цих державних символах уособлюється сама держава та її органи влади. На нашу думку, через це більш коректно стверджувати про наявність у складі злочину, описаного у вироку Мукачівського міськрайонного суду Закарпатської області від 20 грудня 2018 року у справі № 303/6698/18, саме мотивів явної неповаги до України.

Тотожними також убачаються хуліганські мотиви та мотиви явної неповаги до суспільства. Згідно із ч. 1 ст. 296 КК України хуліганство - це грубе порушення громадського порядку 3 мотивів явної неповаги до суспільства, що супроводжується особливою зухвалістю чи винятковим цинізмом [15].

Наведене свідчить про те, що так звані «хуліганські мотиви» - це і є мотиви явної неповаги до суспільства, більше того, остання назва $є$ більш коректною.

Доволі складними з точку зору кваліфікації дій виглядають ситуації, за яких особа, грубо порушивши громадський порядок із мотивів явної неповаги до суспільства, також вчинила наругу над державними символами України.

Наприклад, у згаданому вироку Лановецького районного суду Тернопільської області від 15 листопада 2012 року у справі № 1910/896/2012 описується ситуація, в якій неповнолітній ОСОБА_4, будучи у стані алкогольного сп'яніння, 26 травня 2012 року о 22 годині 40 хв. на шкільному подвір'ї Якимівської ЗОШ I-II ступенів, що в с. Татаринці Лановецького району, грубо порушуючи громадський порядок із мотивів явної неповаги до суспільства, безпричинно $з$ хуліганських спонукань у присутності сторонніх осіб, виявляючи зневажливе ставлення до Державного Прапора України, який був офіційно встановлений біля центрального входу у школу 3 нагоди свята останнього дзвінка, за допомогою запальнички вчинив його підпал [14].

Для того аби правильно кваліфікувати дії суб’єкта злочину, важливо встановити не тільки факт наруги над Державним Прапором України, але і з'ясувати, чи дійсно вказана дія була пов'язана із грубим порушенням громадського порядку з мотивів явної неповаги до суспільства.

Дана робота у вказаному випадку була проведена. Так, свідок ОСОБА 7 суду пояснив, що 26 травня 2012 року він разом зі своїми друзями ОСОБА_4, ОСОБА_9, ОСО̄БА_10, ОСОБА_6, ОСОБА_8 та ОСОБА_11 відпочивав у саду с. Татаринці, розпалили багаття, вживали спиртні напої, потім вони розійшлися по домівках, однак йшли не всі разом, а невеликими компаніями. Він йшов з ОСОБА_4, ОСОБА_8 та ОСОБА_6. Проходячи через територію шкільного подвір'я, вони з ОСОБА_4 почали виривати квіти, які росли на шкільній клумбі, та розкидати їх, при цъьому вживали нецензурні слова, а потім він випадково зачепився за флагшток прапора, розташованого на подвір'ї і зігнув його, а ОСОБА_4 підпалив прапор, який впав на землю. Він хоч і старший за віком, але оскільки був п'яним, не зміг зупинити свого неповнолітнього товариша [14].

Отже, в цьому випадку ОСОБА_4 вчиняв хуліганські дії, під час яких здійснив наругу над Державним Прапором України.

Для правильної кваліфікації означених дій слід звернутися до Постанови Пленуму Верховного Суду України від 22.12.2006 № .10 «Про судову практику у справах про хуліганство». Так, згідно з п. 13 під час вирішення питання про кваліфікацію дій винних осіб, які під час грубого порушення громадського порядку з мотиву явної неповаги до суспільства вчинили й інші злочини, передбачені різними статтями Особливої частини КК (2341-14), судам належить виходити з положень ст. 33 цього Кодексу [16].

Названа ст. 33 КК України «Сукупність злочинів» передбачає:

«1. Сукупністю злочинів визнається вчинення особою двох або більше злочинів, передбачених різними статтями або різними частинами однісї статті Особливої частини цього Кодексу, за жоден з яких її не було засуджено. При цьому не враховуються злочини, за які особу було звільнено від кримінальної відповідальності за підставами, встановленими законом. 
2. У випадку сукупності злочинів кожен із них підлягає кваліфікації за відповідною статтею або частиною статті Особливої частини цього Кодексу» [15].

Таким чином, якщо особа під час хуліганства вчинила також наругу над державними символами України, ії дії слід кваліфікувати як сукупність злочинів, передбачених відповідною частиною ст. 296 КК України та ч. 1 ст. 338 КК України.

Саме так в описаному випадку і вчинив суд. Відтак у вироку зазначено, що, аналізуючи здобуті докази в сукупності, суд вважає, що дії ОСОБА_4 вірно кваліфіковано органом досудового слідства за ч. 1 ст. 296 КК України як хуліганство, тоббто грубе порушення громадського порядку з мотивів явної неповаги до суспільства, що супроводжується особливою зухвалістю, та ч. 1 ст. 338 КК України як публічна наруга над Державним Прапором України. Врешті-решт, особа була визнана винною у вчиненні злочинів, передбачених ч.1 ст. 296, ч.1 ст. 338 КК України [14].

Отже, в переважній більшості випадків суди не визначають мотиви вчинення злочину, передбаченого ч. 1 ст. 338 КК України. Нами виявлено дві групи мотивів, які зустрічаються на практиці: явна неповага до України та явна неповага до суспільства (хуліганські).

Доречними є зауваження авторів «Науково-практичного коментаря Кримінального кодексу України» за ред. М.I. Мельника та М.I. Хавронюка про те, що оскільки мотив наруги над державними символами України не має значення для кваліфікації, то такі дії, вчинені з хуліганських мотивів, кваліфікуються тільки за ч. 1 ст. 338 КК України [9, с. 1050].

Дійсно, у вказаній вище ситуації суд засудив суб'єкта злочину за сукупністю злочинів, передбачених ч. 1 ст. 296 та ч. 1 ст. 338 КК України не через встановлені мотиви, а тому що під час грубого порушення громадського порядку з мотивів явної неповаги до суспільства (виривав квіти, які росли на шкільній клумбі, та розкидав їх, при цьому вживав нецензурні слова) він вчинив $\mathrm{i}$ інший злочин - наругу над державними символами України.

Розглянемо іншу факультативну ознаку суб'єктивної сторони наруги над державними символами України - мету.

Мета злочину - це ідеалізоване уявлення особи про злочинний результат, якого вона прагне досягти своїми діями. Мета злочину органічно пов'язана 3 мотивом злочину та дозволяє визначити, заради чого, до якого результату спрямована її суспільно небезпечна діяльність (у той час як мотив злочину - чому особа вчиняє злочин). Мета та мотив злочину є психологічною основою для утворення в суб'єкта винного ставлення до здійснюваного діяння [17, с. 164].

На практиці лише у 6\% випадків (два випадки) судом було встановлено мету вчинення наруги над державними символами України. Так, у згаданих вироках Дзержинського міського суду Донецької області від 12 лютого 2016 року у справі № 225/985/16-к [18] та Слов’янського міськрайонного суду Донецької області від 21.03.2016 року у справі № 243/2086/16-к (номер провадження: 1-кп/243/305/2016) [19] ними були визнані підривання авторитету держави та приниження тих цінностей, до яких інші члени суспільства ставляться з повагою.

В інших же випадках про мету або не згадується взагалі, або ж ії характеризують як «мета реалізації злочинного наміру») [20].

Висновки. Отже, обов'язковою ознакою суб'єктивної сторони складу суспільно небезпечного діяння у вигляді наруги над державними символами України є вина, що виражається у формі умислу, вид умислу - прямий.

Факультативними ознаками суб'єктивної сторони складу злочину, передбаченого ч. 1 ст. 338 КК України, можуть виступати мотив (на практиці виявлено дві групи мотивів: явної неповаги до України та явної неповаги до суспільства) та мета (на практиці зустрічається два випадки встановлення мети: підривання авторитету держави та приниження тих цінностей, до яких інші члени суспільства ставляться з повагою), втім, у більшості випадків, на жаль, суди не приділяють уваги встановленню цих ознак.

\section{Список використаних джерел:}

1. Смельянов В.П. Кримінальне право України: Загальна частина. Основні питання вчення про злочин : наук.-практ. посіб. Харків : Право, 2018. 142 с.

2. Дудоров О.О., Хавронюк М.І. Кримінальне право : навчальний посібник / За заг. ред. М.I Хавронюка. Київ : Ваіте, 2014. 944 с.

3. Конституція України : Закон України від 28.06.1996 p. № 254к/96-ВР // База даних «Законодавство України» / Верховна Рада України. URL : http://zakon5.rada.gov.ua/laws/show/ 254к/96-вр. (дата звернення: 03.05.2019 р.).

4. Вереша Р.В. Умисел і його види (коментар до ст. 24 КК України). Вісник Академії адвокатури України. 2010. № 3(19). С. 73-82. 
5. Куц В., Бондаренко О. Зміст вини у злочинах з формальним складом. Вісник Національної академії прокуратури України. 2009. № 3. С. 36-40.

6. Вирок Южного міського суду Одеської області від 22.02.2019 року по справі № 519/816/17 (номер провадження: 1-кп/519/10/18) // Єдиний державний реєстр судових рішень. URL : http://reyestr.court.gov.ua/Review/72368269 (дата звернення: 22.10.2019).

7. Вирок Мукачівського міськрайонного суду Закарпатської області від 20.12.2018 року по справі № 303/6698/18 // Єдиний державний реєстр судових рішень. URL : http://www.reyestr.court. gov.ua/Review/78733860 (дата звернення: 22.10.2019).

8. Науково-практичний коментар Кримінального кодексу України станом на 20 січня 2018 року / За заг. ред. Глунька В.В. Київ : Видавничий дім «Професіонал», 2018. 784 с.

9. Науково-практичний коментар Кримінального кодексу України / за ред. М.I. Мельника, М.I. Хавронюка. 10-те вид., переробл. та допов. Київ : ВД «Дакор», 2018. 1368 с.

10. Кримінальне право України: Особлива частина : підручник / Ю.В. Баулін, В.І. Борисов, С.Б. Гавриш та ін.; за ред. проф. В.В. Сташиса, В.Я. Тація. 3-є вид., перероб. і допов. Київ : Юрінком Інтер, 2007. 624 с.

11. Савченко А.В., Шуляк Ю.Л. Кримінальне право України. Загальна та Особлива частини (у схематичних діаграмах) : навчальний посібник. Київ : Центр учбової літератури, 2015. 312 с.

12. Вирок Городоцького районного суду Львівської області від 30.08.2018 року по справі № 441/1001/18 // Єдиний державний реєстр судових рішень. URL : http://reyestr.court.gov.ua/ Review/76168567 (дата звернення: 22.10.2019).

13. Вирок Коростенського міськрайонного суду Житомирської області від 03 квітня 2019 року по справі № 279/1037/19 // Єдиний державний реєстр судових рішень. URL : http:// reyestr.court.gov.ua/Review/80899381 (дата звернення: 22.10.2019).

14. Вирок Лановецького районного суду Тернопільської області від 15.11 .2012 року по справі № 1910/896/2012 // Єдиний державний реєстр судових рішень. URL : http://reyestr.court. gov.ua/Review/29923396 (дата звернення: 22.10.2019).

15. Кримінальний кодекс України : Закон України від 05.04.2001 p. № 2341-III // База даних «Законодавство України» / Верховна Рада України. URL : http://zakon3.rada.gov.ua/laws/ show/2341-14 (дата звернення: 03.05.2019 р.).

16. Про судову практику у справах про хуліганство : Постанова Пленуму Верховного Суду України від 22.12.2006 № .10 // База даних «Законодавство України» / Верховна Рада України. URL : https://zakon.rada.gov.ua/laws/main/va010700-06 (дата звернення: 03.05.2019 p.).

17. Практикум ыз кримінального права України (Загальна частина) : навчальний посібник / О.В. Ведмідський, В.Д. Людвік, В.Ф. Примаченко та ін. ; за заг. ред. д.ю.н., доц. В.В. Шаблистого. Дніпро : Дніпропетровський державний університет внутрішніх справ, 2017. 352 с.

18. Вирок Дзержинського міського суду Донецької області від 12 лютого 2016 року по справі № 225/985/16-к (номер провадження: 1-кп/225/148/2016) // Єдиний державний реєстр судових рішень. URL : http://reyestr.court.gov.ua/Review/56320656 (дата звернення: 22.10.2019).

19. Вирок Слов'янського міськрайонного суду Донецької області від 21.03.2016 року по справі № 243/2086/16-к (номер провадження: 1-кп/243/305/2016) // Єдиний державний реєстр судових рішень. URL : http://reyestr.court.gov.ua/Review/56561816 (дата звернення: 22.10.2019).

20. Вирок Артемівського міськрайонного суду Донецької області від 20.11.2015 року по справі № 219/9481/15-к (номер провадження: 1-кп/219/671/2015) // Єдиний державний реєстр судових рішень. URL : http://reyestr.court.gov.ua/Review/53667435 (дата звернення: 22.10.2019). 